Conference Report

\title{
A Primer on Disability Discrimination in Higher Education
}

\section{Laura Rothstein}

Louis D. Brandeis School of Law, University of Louisville, Louisville, KY 40292, USA;

laura.rothstein@louisville.edu

Received: 15 March 2018; Accepted: 25 June 2018; Published: 28 June 2018

Abstract: This article provides an overview of key issues and a focus on some of the most significant and important recent developments that should be given a high priority by university attorneys and higher education administrators and policymakers. It emphasizes the role that administrators responsible for facilitating or coordinating disability services on campus can play in ensuring that faculty members, staff members, and other administrators have the knowledge and tools to ensure access and also to avoid liability to the institution. Major changes in the Trump administration and Congress may signal changes that could affect disability discrimination issues on campus. These changes include changed regulatory guidance, reduced appropriations (including ripple effects from funding for veterans and vocational rehabilitation), and enforcement approaches. While repeal of the ADA is unlikely, regulatory activities might affect its impact.

Keywords: disability; accommodation; discrimination

\section{Introduction}

The article will

(1) Highlight the most important disability issues in higher education today and why:

- Most importantly because:

- Costly (buildings, technology, auxiliary aids and other accommodations)

- Getting current enforcement and litigation attention (technology, food, animals)

- Extremely challenging (mental health issues)

- Evolving and changing (technology)

- Confusing (otherwise qualified, reasonable accommodations for learning disabilities, documentation of disability)

- Concerns about safety and qualifications (issues in professional education, especially health care programs)

(2) Priority for attention

- Cost issues-shrinking resources

- Changes in enforcement by Department of Education and Department of Justice

- Changes in federal appropriations affecting disability services on campus

- Technology-particularly websites

- Accommodations and related documentation issues

- Animals on campus

- Mental health issues 
- Physical plant

- Health care professional program issues

- Faculty issues

(3) Provide a basic reference on the sources of legal guidance for addressing these issues

- $\quad$ Statutes and regulations

- Agency guidance

- Regulatory guidance

- Judicial decisions

- Case settlements

(4) Provide principles and framework for compliance

- Holistic approach-avoiding silos

- Proactive approach

- Individualized and interactive

- Consistency

(5) Provide a prediction of issues to watch in light of federal government changes in administration and Congress and in light of financial challenges

- Funding-vocational rehabilitation funding for auxiliary services may impact budgets for accommodations such as interpreters

- Aging faculty members who do not retire but whose performance is deficient (attention to issue of "otherwise qualified")

- Department of Education guidance on "danger to self" —enforcement impact?

- Professional education—shift in deference to institutions in setting requirements

- Enforcement

- Pulling back regulations and guidance

(6) Questions to be considered include:

- What are today's hot legal issues for higher education?

- What are likely areas of litigation?

- What are courts and the Office for Civil Rights likely to do?

- What is the impact of recent judicial settlements?

- How have the Trump administration and Congress changed the landscape?

- How can higher education administrators, legal counsels involved in these issues, and disability service providers proactively ensure that Section 504 and ADA requirements are followed with a minimum of litigation and confrontation?

- And how can they do so proactively and positively and in the spirit of the intent of these laws in a time of shrinking resources and a growing numbers of students, staff, and faculty members with disabilities?

(7) Provide frameworks for procedures to address disability issues on campus in a way that is

- Proactive-including anticipating training for various stakeholders on campus and information to provide to those who may require disability accommodations or services and creating a position for an ADA coordinator on campus whose responsibility involves all stakeholders, not just students and employees

- Responsive as "reactive" as situations arise

- Interactive-demonstrating flexibility to individualized types of issues 
(8) Provide a framework for the creation of an ADA Coordinator position on campus to facilitate a holistic approach to addressing all disability issues on campus not just those directly affecting students, staff, and faculty by considering the idea of a centralized position to respond to all issues.

\section{Article Description}

Section 504 of the 1973 Rehabilitation Act required that programs receiving federal financial assistance do not discriminate on the basis of "handicap" (later disability). The enormous impact of this law (and later the Americans with Disabilities Act, enacted in 1990) on higher education was probably not foreseen in 1973. Before 1980, very little response to the Rehabilitation Act occurred. Since then, however, disability issues on campus have evolved. The challenges and complexities of technology, shrinking resources, increasing mental health concerns, and other issues make it critical to understand and appreciate the requirements of disability discrimination law for those who make and implement policy at the macro and micro levels as well as those who enforce and defend these issues in litigation, compliance reviews, and OCR interventions.

Hot topics that will be given focus include documentation requirements for accommodation (including documentation challenges for students transitioning from K-12 to undergraduate programs and later to graduate and professional programs), how to determine what are essential requirements and fundamental alterations; ensuring accessible technology (websites, online courses, and E-readers), service and comfort animals as accommodations in settings ranging from housing to the classroom to employment on campus and focusing on documentation related to those different settings.

While undue burden has rarely been raised as a defense in judicial decisions, shrinking resources in higher education and the increasing population of students with disabilities on campus may change that. This may be even more likely under the current Trump administration and Congressional budgeting proposals. The probability of "undue burden" as a defense and issues that arise in such cases will be addressed. The issue of financial costs, however, should be a consideration in setting a tone of proactive and positive approach to ensuring access on campus. Dispute resolution has financial costs, time costs for personnel, and public relations costs that often can be avoided.

The approach of the article is to address what the areas of litigation or complaints to OCR are likely to be (and why), how disputes about whether the requirements have been violated are likely to be resolved, how campus service providers, administrators, policymakers, and faculty members (and the students themselves) can be proactive in addressing what is required, what is not required, and how to best accomplish the goals of current law, and how a model of implementing an ADA coordinator position could be most effective in addressing these issues.

The article will suggest a bit about what the Trump administration (particularly leadership at the Department of Justice, the Department of Education, and the Department of Health and Human Services) is bringing to disability law and current Congressional trends that might have an impact.

\section{The Statutory and Regulatory Framework}

The primary statutes relevant to these issues are Section 504 of the Rehabilitation Act and the Americans with Disabilities Act. These statutes are intended to be interpreted consistently. Section 504 applies to higher education institutions receiving federal financial assistance (which is almost all colleges and universities). The ADA applies to employment (Title I) and programs and services provided by private entities (Title III) and by state and local governmental entities (Title II). Although Section 504 is relatively short in terms of language, the ADA (which is intended to be read consistently with Section 504) has extensive language that incorporates much of the judicial interpretation from the cases decided before 1990. The 2008 amendments added even greater clarification to the requirements of the statute. Congress intended that the ADA be given a broad interpretation. 


\section{Who Is Protected}

- Must be substantially limited in one or more major life activities; be regarded as so impaired or have a record of such an impairment.

- Must be otherwise qualified-able to carry out the essential functions of the program with or without reasonable accommodation. Undue hardship, fundamental alteration, lowering standards-not required.

- Individual must not pose a direct threat to self (not clear whether this applies outside of the employment context), property, or others.

- Individual must make "known" the disability and have appropriate documentation, and must do so in a timely manner in order to demonstrate that the program discriminated or failed to provide a reasonable accommodation.

The ADA Amendments Act of 2008 clarifies and amends the definition of "disability. ${ }^{1}$ The EEOC regulations pursuant to the amendments were promulgated on 25 March 2011, effective 24 May 2011. They can be found at 29 C.F.R. 1630 and are available through the website at www.eeoc.gov.

The amendments respond to 1999 and 2002 Supreme Court decisions that had narrowed the definition, and provides for a broad interpretation of the definition of disability under the ADA. Under the revisions, whether an individual is substantially limited is to be determined without reference to mitigating measures, with an exception for ordinary eyeglasses and contact lenses. ${ }^{2}$

The amendments also add an illustrative list of major life activities, and by doing so, codify the existing regulatory definitions and add to them.

The revised definition of major life activities specifically includes caring for oneself, performing manual tasks, seeing, hearing, eating, sleeping, walking, standing, lifting, bending, speaking, breathing, learning, reading, concentrating, thinking, communicating, working, and operating major bodily functions (which are further defined). Many of the conditions found not to be disabilities may prospectively be determined to fall within the definition, so long as the condition substantially limits one or more of those major life activities.

The Amendments specifically provide that concentrating, thinking, and communicating are major life activities. This amendment may make it more likely that an individual with a learning disability or with certain mental impairments will fall under the definition.

The Amendments clarified that major life activities include, but are not limited to, caring for oneself, performing manual tasks, seeing, hearing, eating, sleeping, walking, standing, lifting, bending, speaking, breathing, learning, reading, concentrating, thinking, communicating and working. ${ }^{3}$ [A] major life activity also includes the operation of a major bodily function, including but not limited to, functions of the immune system, normal cell growth, digestive, bowel, bladder, neurological, brain, respiratory, circulatory, endocrine, and reproductive functions. ${ }^{4}$

To meets the requirement of "being regarded as having such an impairment" the individual must establish "that he or she has been subjected to an action prohibited under this Act because of an actual or perceived physical or mental impairment whether or not the impairment limits or is perceived to limit a major life activity." ${ }^{\prime 5}$

The definition of disability does not apply to impairments that are transitory and minor. A transitory impairment is one with an actual or expected duration of 6 months or less. ${ }^{6}$

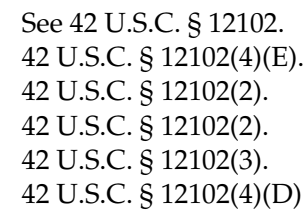


The 2008 amendments further clarify that the determination of whether an impairment substantially limits a major life activity is to be made without regard to the ameliorative effects of mitigating measures. There is an exception for eyeglasses or contact lenses, but covered entities are prohibited from using qualification standards or selection criteria that are based on uncorrected vision unless these are job-related and consistent with business necessity. ${ }^{7}$

The Amendments also provide that

"Nothing in this Act alters the provision ... , specifying that reasonable modifications in policies, practices, or procedures shall be required, unless an entity can demonstrate that making such modifications in policies, practices, or procedures, including academic requirements in postsecondary education, would fundamentally alter the nature of the goods, services, facilities, privileges, advantages or accommodations involved." 8

The ADA Amendments of 2008 (42 U.S.C. § 12103(1)) codify the basic provisions of the ADA and Rehabilitation Act regulations by providing that auxiliary aids and services are to include:

- qualified interpreters or other effective methods of making aurally delivered materials available to individuals with hearing impairments;

- qualified readers, taped texts, or other effective methods of making visually delivered materials available to individuals with visual impairments;

- acquisition or modification of equipment or devices; and

- other similar services and actions.

The Amendments state that the definitions are also to be applied to the Rehabilitation Act. 29 U.S.C. § 705(9)(B), incorporating 42 U.S.C. § 12102.

\section{Regulatory Guidance}

Although federal agencies were initially slow in promulgating regulations under disability discrimination law (it was not until 1978 that model regulations for Section 504 were finalized), in the 30 years since the first set of regulations, the agencies responsible for various aspects of disability discrimination law have provided not only many sets of regulations, but substantial regulatory "guidance" in the form of frequently asked questions answers, Office for Civil Rights (OCR) opinions, and other useful information. Statutes that are related to Section 504 and the ADA are also important to incorporate for overall policy. These agencies include the Department of Justice (for Title II and Title III of the ADA), the Department of Education (for Title II and Title III of the ADA and for the Individuals with Disabilities Education Act), EEOC (for Title I of the ADA and Section 504), Health and Human Services, and Housing and Urban Development.

The Trump administration has significantly changed the status of at least some regulatory guidance. Regulations promulgated shortly before the change in presidency are subject to "repeal" without the usual notice and public comment. Many agency websites that provided substantial guidance were taken down after President Trump took office, and much guidance that does not have the weight of official regulations now remains uncertain in terms of its impact. The information below primarily reflects the status of statutes, regulations, guidance, and judicial opinions before January 2017.

Major regulatory changes for Title II and Title III were issued by the Department of Justice in 2010, and there are several significant aspects of those changes that affect higher education. These include stadiums and swimming pools. There is also change-defining housing on campus (ADA 2012).

In 2016, the DOJ issued additional regulatory clarifications regarding documentation of disabilities for testing purposes. ${ }^{9}$

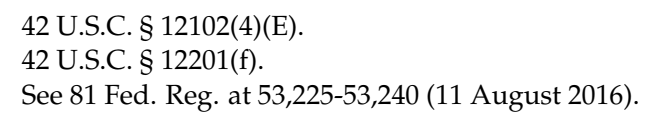


DOJ regulatory assessment issued on 10 February 2016 on ADA Titles II and III regulations on additional time at postsecondary institutions and national exams are accommodations most likely to have significant, measurable costs which include staff training, processing requests, and proctoring. Societal cost is estimated between $\$ 31.4$ and $\$ 47.1$ million (ADA 2016).

\section{OSERS Publishes Transition Guide to Postsecondary Education}

The Office of Special Education and Rehabilitative Services (The Office of Special Education and Rehabilitative Services OSERS) published a guide in January 2017 to help students and their parents to transition from school to post-school activities: "A Transition Guide to Postsecondary Education and Employment for Students and Youth with Disabilities". The Department of Education has created and funded a new National Center for Information and Technical Support for Postsecondary Students with Disabilities to provide assistance and information about a number of practices for students with disabilities transitioning from high school to college (Federal Register 2015).

\section{Increased Graduation Rates for K-12 Students Impact Higher Education}

According to Department of Education statistics, the national graduation rate for students with disabilities is 61.9 percent, but state by state percentages vary greatly (Samuels 2015; Diament 2015).

\section{Judicial Interpretation}

It was not until the mid-1980s that much judicial guidance was provided to interpret disability discrimination law in the higher education (or any) context. That is because Section 504 only applied to recipients of federal financial assistance. While institutions of higher education were such programs, because the special education statutes (Individuals with Disabilities Education Act of 1975 as amended) took some time to implement, students were not immediately prepared for college level work. As this evolved over time, the courts spent a great deal of attention on interpreting these issues. The following are the key cases, and recent interpretations. Additional citations can be found in Disabilities and the Law (Rothstein and Irzyk 2018) (published by Thomson Reuters (4th edition) which is updated twice a year).

\section{Key Cases}

The first Supreme Court decision to address any Section 504 issue was in the context of higher education.

Southeastern Community College v. Davis, 442 U.S. 397 (1979). This decision established the definition of "otherwise qualified" in the context of a nursing student with a significant hearing impairment. It set out the basic requirement that to be otherwise qualified one must meet the essential requirements of the program with or without reasonable accommodation.

Although it is not a Supreme Court case, the following decision is important because it has the weight of a Supreme Court decision and is frequently cited by courts as the standard for determining whether an institution must provide a requested accommodation.

Wynne v. Tufts University School of Medicine, 932 F.2d 19, 26 (1st Cir. 1991). In cases involving modifications and accommodations, the burden is on the institution to demonstrate that

- relevant officials within the institution

- considered alternative means, their feasibility, cost and effect on the program,

- and came to a rationally justifiable conclusion

- that the alternatives would either lower academic standards or require substantial program alteration. 


\section{Cases Below Are Arranged Alphabetically}

The following case citations represent some of the most significant decisions (particularly recent cases) on a range of key issues. Additional cases citations can be found in Disabilities and the Law, referenced previously.

\section{Procedural and Enforcement Issues}

Individuals seeking protection against discrimination generally have the option of making an administrative complaint to the appropriate agency or seeking relief in court. Of particular recent interest are the following two decisions. The first demonstrates the high cost to an institution of prolonging disputes. The second reflects a growing number of decisions that expect entities to engage in an interactive process to resolve disagreements about accommodation issues.

Covington v. McNeese State University, 118 So.2d 343 (S. Ct. La. 2013). The court reversed some of the attorney fee awards and held that district court decisions on the amounts were not an abuse of discretion, but it did not overrule any of the substantive issues. For the facts in this case that lead to the decision, see Covington v. McNeese State University, 98 So.3d 414, 2011-1077 (La.App. 3 Cir.). The court ordered substantial award in attorneys' fees and costs in the case involving 15,000 architectural barriers; the court noted the university's "prolonged 'militant' behavior" over several years of litigation. The initial claim involved the lack of accessible restrooms in the student center.

Schneider v. Shah, 2012 WL 1161584 (D.N.J. 2012). The obligation to engage in an interactive process in accommodations ends on the day the student sues the university. The case involved a student in a paralegal program who had excess absences.

\section{Definition/Documentation Issues and Relationship to Accommodations}

Until the 2008 ADA amendments (which clarified the definition of who is protected), an increasing number of decisions (primarily in the context of employment) had focused on whether the individual was "disabled" within the statutory definition. In higher education, while that was not as frequently an issue, cases involving learning disabilities and mental health issues did raise that question. The following decisions reflect some of the post-2008 amendment decisions in higher education. Cases decided since the amendments tend to focus more on whether the individual is otherwise qualified and on reasonable accommodation issues.

\subsection{Definition of Disability}

Alexiadis v. New York College of Health Professions, 891 F. Supp. 2d 418 (E.D.N.Y. 2012). A College student who was HIV positive was arrested for stealing a bag of hand sanitizer and was dismissed from college. The court allowed the claim to go forward regarding whether he was disabled; whether dismissal was because of disability; and whether explanation was a pretext. It is unusual today that there would be any dispute about whether an individual who is HIV positive has a disability.

Ballard v. Jackson State University, 62 F. Supp. 3d 549 (S.D. Miss 2014). The court denied a claim for associational discrimination by a university compliance officer who claimed his advocacy on behalf of students with disabilities was reason for his termination. The court did not decide whether the Fifth Circuit even recognizes associational discrimination claims, but did determine that this was not the basis for the university's adverse employment action.

Cordova v. University of Notre Dame Du Lac, 936 F. Supp. 2d 1003, 2013 WL 1332268 (N.D. Inc. 2013). A student with learning disability and psychological disability claimed numerous denials of requested accommodations. The case was dismissed due to the statute of limitations for ADA, Rehab Act and state tort law. The court held that isolated bouts of depression did not constitute disabilities under the pre-2008 interpretation of the ADA when the complained actions occurred. It is uncertain whether the student would meet the amended definition today. 
Dickinson v. University of North Carolina, 91 F. Supp. 3d 755, 2015 WL 1185850 (M.D.N.C. 2015). A student with severe migraine headaches and Polycystic Ovary Syndrome was disabled under the revised definition applicable under a 4-year statute of limitations. The case was allowed to proceed on issues disability claim, retaliation, and tortious interference with contract.

Doe v. Samuel Merritt University, 921 F. Supp. 2d 958 (N.D. Cal. 2013). A student with anxiety disorders claimed the right for additional opportunities to take a medical licensing exam. The case was allowed to go forward on issues of whether test-taking is a major life activity and whether limit on taking exams was entitled to deference.

Forbes v. St. Thomas University, Inc., 2010 WL 6755458, 768 F. Supp. 2d 1222 (S.D. Fla. 2010). Issues of material fact remain regarding a law student as to whether post-traumatic stress disorder was a disability and if so whether the student had received reasonable accommodations. The court required some evidence that denial of requests was based on rational belief that no further accommodation could be made without imposing a hardship on the program.

Girard v. Lincoln College of New England, 2014 WL 2766075 (D. Conn. 2014). Summary judgment was precluded because fact issues remained about whether the student's auditory processing impairments were a disability and whether denial of reasonable accommodations violated Section 504.

Ladwig v. Board of Supervisors of Louisiana State University, 842 F. Supp. 2d 1003 (M.D. La. 2012). Doctoral student with recurrent depression and head injury was not substantially limited in a major life activity; accommodation of attendance exceptions was contingent on her providing an accommodation letter to her professors. The court denied retroactive withdrawal or assigning grade of "incomplete" / doctoral student.

Liu v. Northwestern University, 78 F. Supp. 3d 839 (N.D. Ill. 2015). The court allowed a case by a former law student with health conditions to proceed on issues of due process and breach of contract, but held that the alleged defamation by the associate dean was not actionable.

Millington v. Temple University School of Dentistry, 36 Nat'1 Disability L. Rep. II 126 (3d Cir. 2008 (unpublished opinion). Long list of health problems were not sufficiently documented as demonstrating substantial limitation.

North v. Widener University, 869 F. Supp. 2d 630, 2013 WL 3479504 (E.D. Pa. 2013). Disclosing disability after dismissal is not sufficient to give protection. Admission essay about medications for behavior was not sufficient to demonstrate that faculty members knew of his ADHD.

Rumbin v. Association of American Medical Colleges, 2011 WL 1085618 (D. Conn. 2011). Medical school applicant was not disabled. The accommodated convergence ratio was within the normal range. The evaluating optometrist did not compare reading skills to the average person.

Shurb v. University of Texas Health Science Center at Houston-School of Medicine, 63 F. Supp. 3d 700 (S.D. Tex. 2014). A medical student who had been academically withdrawn after hospitalization for anxiety related problems and who had refused to provide the medical documentation required for his return had been provided reasonable accommodations. The university had engaged in an interactive process. The court granted the university's motion for summary judgment.

Singh v. George Washington University School of Medicine, 667 F.3d 1 (D.C. Cir. 2011). The 2008 amendments to the ADA did not apply retroactively to the student's claim. The student failed to establish a relationship of impairment to her performance. The facts arose pre-ADA amendments.

Widomski v. SUNY at Orange, 748 F.3d 471 (2d Cir. 2014). A student whose hands shook too much to draw blood from patients was not perceived to have an impairment limiting a major life activity. He was still employable for medical technician jobs not requiring phlebotomy. The court did not reach the issue of whether he was otherwise qualified.

\subsection{Documentation of Disability and Connection to Accommodation Requests}

Before the 2008 ADA amendments, many disputes in higher education and testing contexts raised a range of issues involving what documentation would be required for an individual to demonstrate that he or she had a disability and/or that the requested accommodation related to that disability. 
Cases in this context also highlight the issue about whether the institution must "know" of the disability (or at least "should know") in taking action to be found to have violated discrimination law. This can arise in the context of whether there is an obligation to give a second chance to a student (or faculty members) whose performance or conduct has not met the requisite standards. Where a disability is discovered after the deficiency, should a second chance be given?

Some clarifications to documentation requirements for examinations under Title II and Title III were issued in 2016. See 81 Fed. Reg. at 53,225-53,240 (11 August 2016).

Department of Justice regulatory assessment issued on 10 February 2016 on ADA Titles II and III regulations on additional time at postsecondary institutions and national exam accommodations most likely to have significant, measurable costs which include staff training, processing requests, and proctoring. Societal cost is estimated between $\$ 31.4$ and $\$ 47.1$ million (ADA 2016).

Bartlett v. New York State Bd. of Law Examiners, 156 F.3d 321, 8 A.D. Cas. (BNA) 996, 8 A.D. Cas. (BNA) 1004 (2d Cir. 1998), cert. granted, judgment vacated on other grounds, 527 U.S. 1031, 119 S. Ct. 2388, 144 L. Ed. 2d 790, 9 A.D. Cas. (BNA) 768 (1999). This case discusses the deference to be given to individual's versus Board of Law Examiners' experts.

Buescher v. Baldwin Wallace University, 86 F. Supp. 3d 789 (N.D. Ohio 2015). The court found no violation of the ADA when a student in a nursing program failed to request accommodations for learning disability. The court cited Johnson v. Washington County Career Center, 470 Fed. Appx. 433 (6th Cir. 2012) ("A publicly funded academic institution is not obligated to accommodate under the ADA until receiving a proper diagnosis and request for specific accommodation.")

Choi v. University of Texas Health Science Center at San Antonio, (5th Cir. 2015). A dental student with ADD was dismissed after failures in clinical courses. The student informed the university after the diagnosis. The court held that it was not the case that the university should have known of his disabilities. The student had duty to timely inform and request accommodation and did not do so.

D'Amico v. New York State Bd. of Law Examiners, 813 F. Supp. 217, 1 A.D.D. 499, 2 A.D. Cas. (BNA) 534 (W.D. N.Y. 1993). The court found that the treating physician's opinion should be given "great weight" because the accommodations issue is essentially a medical issue.

Dixson v. University of Cincinnati, 31 Nat'1 Disability L. Rep. II 123, 2005 WL 2709628 (S.D. Ohio 2005). A graduate student must establish that conditions of bipolar disorder, dyslexia, and attention deficit disorder substantially limit major life activities. The student's history of academic success worked against demonstrating these limitations.

Doe v. Samuel Merritt University, 921 F. Supp. $2 d 958$ (N.D. Cal. 2013). A student with anxiety disorders claimed the right for additional opportunities to take the medical licensing exam. The case was allowed to go forward on issues of whether test-taking is a major life activity and whether a limit on taking exams was entitled to deference.

Edmunds v. Board of Control of Eastern Michigan University, 40 Nat'l Disability L. Rep. II 117, 2009 WL 5171794 (E.D. Mich. 2009). The court granted a summary judgment against a student seeking accommodations because the student did not allow good faith interactive process. Although the process was lengthy, it was necessary to resolve the request for accommodations to the clinical off-campus program.

Forbes v. St. Thomas University, Inc., 2010 WL 6755458, 768 F. Supp. 2 d 1222 (S.D. Fla. 2010). Issues of material fact remain regarding a law student as to whether post-traumatic stress disorder was a disability and, if so, if the student had received reasonable accommodations. The court required some evidence that denial of requests was based on rational belief that no further accommodation could be made without imposing a hardship on the program.

Elmhurst College, 33 Nat'1 Disability L. Rep. II 255 (OCR 2006). A student with cerebral palsy and learning disability objected to policy requiring him to self-identify to instructors to receive approved accommodations. The court found that the procedures were reasonable.

Gill v. Franklin Pierce Law Center, 899 F. Supp. 850, 10 A.D.D. 70, 104 Ed. Law Rep. 234 (D.N.H. 1995). A law student who was dismissed claimed that the law school was given notice 
that he required accommodations because he had stated in his application that he was an adult child of an alcoholic and that this caused him to have post-traumatic shock syndrome. The court held that although he did identify himself as an adult child of an alcoholic, he had not disclosed the shock syndrome or any need for accommodations as a result.

Girard v. Lincoln College of New England, 2014 WL 2766075 (D. Conn. 2014). Summary judgment was precluded because fact issues remained about whether the student's auditory processing impairments were a disability and whether denial of reasonable accommodations violated Section 504.

Guckenberger v. Boston University, 974 F. Supp. 106, 7 A.D. Cas. (BNA) 484, 121 Ed. Law Rep. 541 (D. Mass. 1997). The court discussed the credentials of the evaluators and found that the university's policy of requiring re-evaluations by certified experts every 3 years was impermissible.

Hanlon v. Board of Regents, University of Wisconsin System, 2004 WI App 88, 272 Wis. 2d 856, 679 N.W.2d 927 (Ct. App. 2004). A physician assistant student with asthma failed to provide evidence that the university knew of disability before it dismissed her.

In re Reasonable Testing Accommodations of LaFleur, 2006 SD 86, 722 N.W.2d 559, 18 A.D. Cas. (BNA) 1487 (S.D. 2006). The court discounted the expertise of the psychologist testifying on extra time for an individual with ADD when expertise was not on bar exam accommodations.

Ladwig v. Board of Supervisors of Louisiana State University, 842 F. Supp. 2d 1003 (M.D. La. 2012). A doctoral student with recurrent depression and head injury was not substantially limited in a major life activity. The court held that accommodation of attendance exceptions was contingent on her providing an accommodation letter to professors and the court denied retroactive withdrawal or assigning grade of "incomplete" for the doctoral student; Ladwig v. Board of Sup'rs of Louisiana State University and Agr. and Mechanical College, 481 Fed. Appx. 239 (5th Cir. 2012). A doctoral student with depression and anxiety did not make out the Title I or Title II case. The student did not make out the case that she was qualified to perform essential functions of graduate assistantship and did not adequately request accommodations for head injury excusing her from attendance and allowing additional time to turn in assignments. The university had provided accommodations by providing letters supporting absences and extra time.

Leacock v. Temple University School of Medicine, 14 Nat'1 Disability L. Rep. II 30, 1998 WL 1119866 (E.D. Pa. 1998). A medical student with a learning disability did not make known the disability during first year or before dismissal.

Letter to The Art Institute of Pittsburgh, 33 Nat'1 Disability L. Rep. II 49 (OCR 2005). A student must follow procedures including submitting documentation and requests for accommodations in a timely manner; the student had received a handbook indicating the steps needed for accommodations.

Letter to Central New Mexico Community College, 37 Nat'l Disability L. Rep.II 186 (OCR 2007). Community college documentation requirements should not be overly burdensome and should seek the minimum amount of information needed to establish disability or to support an accommodation request.

Liu v. Northwestern University, 78 F. Supp. 3d 839 (N.D. Ill. 2015). The court allowed a case by a former law student with health conditions to proceed on issues of due process and breach of contract, but held that the alleged defamation by the associate dean was not actionable.

Millington v. Temple University School of Dentistry, 36 Nat'l Disability L. Rep. II 126 (3d Cir. 2008 (unpublished opinion). A long list of health problems were not sufficiently documented as demonstrating substantial limitation.

Mucci v. Rutgers, 42 Nat'1 Disability L. Rep. II 250, 2011 WL 831967 (D.N.J. 2011). A law student with diabetes and stress-induced anxiety did not provide sufficient documentation to justify requested accommodations for a take-home exam. The documentation was not from a physician and did not include a formal diagnosis.

Nathanson v. Medical College of Pennsylvania, 926 F.2d 1368, 66 Ed. Law Rep. 35 (3d Cir. 1991). A medical student with record of a back condition indicated need for special seating. 
North v. Widener University, 869 F. Supp. 2d 630, 2013 WL 3479504 (E.D. Pa. 2013) Disclosing disability after dismissal is not sufficient to give protection. An admission essay about medications for behavior was not sufficient to demonstrate that faculty members knew of his ADHD.

Rivera Concepcion v. Puerto Rico, 682 F. Supp. 2d 164, 255 Ed. Law Rep. 619 (D.P.R. 2010). A student's erratic behavior resulting from previously undiagnosed bipolar disorder should have alerted the internship program of a possible disability-requiring accommodation. Fact issues remained on whether expulsion was based on disability.

Rossomando v. Board of Regents of University of Nebraska, 2 F. Supp. 2d 1223, 127 Ed. Law Rep. 142 (D. Neb. 1998). An orthodontics student failed to request accommodations before failure in an academic program.

Rumbin v. Association of American Medical Colleges, 2011 WL 1085618 (D. Conn. 2011). Medical school applicant was not disabled. The accommodated convergence ratio was within the normal range. The evaluating optometrist did not compare reading skills to the average person.

Salvador v. Bell, 622 F. Supp. 438, 29 Ed. Law Rep. 239 (N.D. Ill. 1985), judgment aff'd, 800 F.2d 97, 34 Ed. Law Rep. 1010 (7th Cir. 1986) It is not a violation of 504 where the institution had no knowledge that the individual had a learning disability.

Shamonsky v. Saint Luke's School of Nursing, 36 Nat'1 Disability L. Rep. II 202, 2008 WL 724615 (E.D. Pa. 2008). The school was not aware of nursing the student's learning disability which was diagnosed after dismissal for poor academic performance.

Shurb v. University of Texas Health Science Center at Houston-School of Medicine, 63 F. Supp. 3d 700 (S.D. Tex. 2014). A medical student who had been academically withdrawn after hospitalization for anxiety-related problems and who had refused to provide the medical documentation required for his return had been provided reasonable accommodations. The university had engaged in an interactive process. The court granted the university's motion for summary judgment.

Singh v. George Washington University School of Medicine, 667 F.3d 1 (D.C. Cir. 2011). The 2008 amendments to the ADA do not apply retroactively to the student's claim. The student failed to establish a relationship of impairment to her performance. The facts arose pre-ADA amendments.

Strujan v. Lehman College, 363 Fed. Appx. 84, 257 Ed. Law Rep. 72 (2d Cir. 2010). The court found that there was no discrimination when the request to withdraw from the course preceded making known a disability.

\section{Otherwise Qualified and Direct Threat}

As noted previously, the 1979 Supreme Court decision sets the standard for what it means to be otherwise qualified. Included in the standard for some situations is whether the individual poses a direct threat to others. Unresolved, is whether a student whose threat is to "self" only can be treated differently based on that threat. While Department of Education opinion is that it would be impermissible to do so, this advisory guidance has been considered by many institutions of higher education to be problematic and presents difficulty in how to deal with students who are self-injurious or suicidal. The high profile shootings on campus have highlighted the challenges this question presents.

\subsection{Otherwise Qualified}

Alexiadis v. New York College of Health Professions, 891 F. Supp. 2d 418 (E.D.N.Y. 2012). A college student who was HIV positive was arrested for stealing a bag of hand sanitizer and dismissed from college. The court allowed the claim to go forward regarding whether he was disabled; whether dismissal was because of disability; and whether explanation was a pretext.

Buescher v. Balwin Wallace University, 2015 WL 506989 (N.D. Ohio 2015). The court found no ADA violation against a student with claimed learning disability in a nursing program when the student did not go to the school's learning center to receive diagnosis. 
Chenari v. George Washington University, 172 F. Supp. 3d 38 (D.D.C. 2016) affirmed 2017 WL 541012 (D.C. Cir. 2017). The court dismissed a suit by a medical student terminated from the program for academic dishonesty. The student did not make known the need for accommodations for attention span, depression and anxiety resulting in diagnosis of ADHD. The misconduct involved continuing to fill in bubble in answers after time was called.

Chin v. Rutgers, 55 Nat'l Disability L. Rep. II 91 (3d Cir. 2017 (unpublished). A medical school student was not qualified for medical school. She had been granted leaves, waivers and extensions, but still failed academic requirements. The treating physician could not assure the medical school that her condition would stabilize in the foreseeable future. The court applied the Wynne test and granted judgment for the university and it was deferred to the judgment of the school.

Doe v. Board of Regents of the University of Nebraska, 846 N.W.2d 126 (S. Ct. Neb. 2014) A medical student with recurrent depressive disorder was terminated from enrollment. His lack of professionalism was the reason for dismissal and was not a pretext.

Halpern v. Wake Forest University Health Sciences, 669 F.3d 454, 2012 WL 627788 (4th Cir. 2012). A medical student with ADHD and anxiety disorder did not request accommodations until several years after engaging in unprofessional acts, including abusive treatment of staff and multiple unexcused absences. The proposed accommodation (allowing psychiatric treatment, participating in program for distressed physicians, and continuing on strict probation) was not reasonable.

Harville v. Texas A\&M University, 833 F. Supp. 2d 645 (S.D. Tex. 2011). It did not violate the ADA to terminate a research assistant because of excess absences.

Herrerra v. Community Coll. Of Allegheny County, 55 Nat'1 Disability L. Rep. II 95 (W.D. Pa. 2017). In a case involving a student with ADHD who was dismissed for not meeting the minimum academic requirements, the court granted summary judgment to college in Title II and 504 claims. The student had been given exam accommodations and had not fully used the remediation resources made available to him.

Johnson v. Washington County Career Center, 982 F. Supp. 2d (S.D. Ohio 2013). A student in surgical technology training with dyslexic LD claimed exclusion and retaliation.

Ladwig v. Board of Supervisors of Louisiana State University and Agricultural and Mechanical College, 2012 WL 292508 (M.D. La. 2012). A doctoral student with depression and anxiety did not make out Title I or Title II case. The student did not make out the case that she was qualified to perform essential functions of graduate assistantship. She did not adequately request accommodations for head injury excusing her from attendance and allowing additional time to turn in assignments. The university had provided accommodations by providing letters supporting absences and extra time.

McCulley v. University of Kansas School of Medicine, 2012 WL 9490568 (D. Kan. 2012). The court granted summary judgment for medical school in the case of an individual with spinal muscular atrophy adversely affecting motor technical standards. The request to have a surrogate to assist during clinical rotations would be a fundamental change to the program.

Morales v. State of New York, 22 F. Supp. 3d 256 (S.D.N.Y. 2014). The court denied Title II violation to the claim by a student alleging a disabling and unpredictable spinal injury and neck injuries. The court deferred to the institutional judgment regarding plagiarism and found that the student's treatment was not discriminatory.

Novak v. Board of Trustees of Southern Illinois University, 777 F.3d 966 (7th Cir. 2015). The lapses of time in assessment of take-home assignment for student with PTSD in a doctoral program did not make out Title II or Rehab Act cases when the student was terminated. This opinion affirmed the lower court. The university had attempted to work with the student on examination accommodations, including allowing several attempts to pass. The grade of the student with PTSD was well below passing and not based on discrimination.

Novak v. Southern Illinois University, 50 Nat'1 Disability L. Rep. II 7 (S.D. Ill 2014). The court granted summary judgment to the university on ADA/Section 504 claims. The student with PTSD could not 
show that disability was the "but for" cause of exclusion from the PhD. program or show disparate treatment by being denied additional opportunities to take preliminary exams after four attempts.

Palmer v. Davenport Civil Rights Commission, 850 N.W. $2 d 326$ (S. Ct. Iowa 2014). The program was discriminatory when it denied admission of a blind student to a chiropractic program. Although the court addressed deference, it stressed the importance of individualized determination. The dissent in the case raises the concern about the implications of the majority opinion.

Peters v. University of Cincinnati College of Medicine, 45 Nat'l Disability L. Rep. II 236 (S.D. Ohio 2012). A medical student with depression, learning disability, and ADD was placed on academic probation. The medical school refused to allow her to retake exams after medication regimen had stabilized because it decided her history of depression and mood swings would prevent her from being a good physician. The court found that evidence that dismissal was because of pattern of psychiatric difficulties might establish a Title II case.

Pierre v. University of Dayton, 143 F. Supp.3d 703 (S.D. Ohio 2015). The court denied injunctive relief when the student did not articulate and express himself verbally during disciplinary procedures involving sexual harassment policy violations. The student claimed he should have received accommodations in that proceeding.

Rivera-Concepcion v. Commonwealth of Puerto Rico, 786 F. Supp. 2d 489, 2011 WL 1938239 (D. Puerto Rico 2011). A student with bipolar disorder was expelled from a government internship program. The student did not make out case of ADA/504 discrimination. The expulsion was based on a manic episode, and the program was not aware of mental condition, but based the expulsion on behavior.

Roggenbach v. Touro College of Osteopathic Medicine, 7 F. Supp. 3d 338 (S.D.N.Y. 2014). Student in an osteopathy program with HIV had a disability. His dismissal was based on conduct violations, not on his HIV status. Judicial deference is to be given to educational administrators on qualifications of students. The program did not know of his HIV status before beginning disciplinary measures.

R.W. v. Board of Regents of University System of Georgia, 2015 WL 4306858 (N.D. Ga. 2015). The court denied summary judgment on the issue of whether a student with schizophrenia was otherwise qualified. The student had been excluded from on-campus housing and enrollment was conditioned on continuing psychiatric treatment. Fact issues remained about the claim that the student was a direct threat.

Schuler v. University of Denver, 50 Nat'1 Disability L. Rep. II 110 (D. Colo. 2014). The court granted summary judgement to the university in a Section 504 claim by a student with insomnia, anxiety, depression and ADD who claimed that leave of absence for health reasons was basis for discriminatory treatment. The student claimed retaliation in handling financial aid status. The student had been advised of steps to return to class and to return to student housing, but did not follow through.

Shah v. University of Texas Southwestern Medical School, 54 F. Supp. 3d 681 (N.D. Tex. 2014). A medical student with ADHD was dismissed because of lack of professionalism during clinical rotations. Title II claims were dismissed on procedural grounds of immunity. The court determined that the Section 504 claim should be dismissed because student did not demonstrate discrimination solely on basis of disability; motivation was by other considerations.

Shaikh v. Lincoln Memorial University, 46 F. Supp. 3d 775 (E.D. Tenn. 2014). A student dismissed from an osteopathic medicine program was not otherwise qualified because of academic deficiencies. Accommodations had been provided (additional exam time, access to lecture notes, class video recordings). Requested accommodations of deceleration of the program was made after a dismissal recommendation and would be unreasonable because it would require changes to the clinical program, financial aid, and accreditation procedures.

Shinabarger v. Board of Trustees of University of District of Columbia, 164 F. Supp. 3d 1, 2016 WL 393180 (D.D.C. 2016). The court found no ADA or 504 violation when a former law student was suspended for student conduct violation of acting in ways deemed threatening to students and faculty.

Singh v. George Washington University School of Medicine, 2011 WL 6118563 (D.D.C. 2011). Causes other than learning disabilities related to academic deficiencies. These included extracurricular 
activities, anxiety, and poor study habits. 667 F.3d 1 (D.C. Cir. 2011) Amendments to the ADA do not apply retroactively to student's claim; student failed to establish a relationship of impairment to her performance.

Sjostrand v. Ohio State University, 930 F. Supp. 2d 886, 2013 WL 1056390 (S.D. Ohio 2013). A Ph.D. program applicant with Crohn's disease had disclosed her condition in the application process. No violation was determined because faculty interviewers had a legitimate basis for not accepting her for the program. Sjostrand v. The Ohio State University, 750 F.3d 596 (6th Cir. 2014). The court remanded for further disposition.

Widomski v. State University of New York at Orange, 748 F.3d 471 (2d Cir. 2014). The court replaced the lower court decision and found that a student whose hands shook too much to draw blood from patients was not perceived to have an impairment limiting a major life activity. The court found that he was still employable for medical technician jobs not requiring phlebotomy. The decision did not reach the issue of whether he was otherwise qualified.

Zimmeck v. Marshall University, 106 F. Supp. 3d 776 (S.D. W. Va. 2015). Granting summary judgment to the university. Medical student removal from the program was based on lack of professionalism (being consistently late and disruptive and failing to sit for a required exam) not her depression.

\subsection{Direct Threat}

Title II regulations provide the following regarding direct threat:

Direct threat means a significant risk to the health or safety of others that cannot be eliminated by a modification of policies, practices or procedures, or by the provision of auxiliary aids or services as provided in $\S 35.139 .28$ C.F.R. $\S 35.104$ (definitions).

The determination of direct threat is to be based on an individualized assessment based on reasonable judgment that relies on current medical knowledge or on the best available objective evidence to ascertain the nature, duration, and severity of the risk; the probability that the potential injury will actually occur; and whether reasonable modifications of policies, practices or procedures or the provision of auxiliary aids or services will mitigate the risk. ${ }^{10}$

Title I regulations applicable to employment, however, allow direct threat as a defense when the individual poses a direct threat to the health or safety of the individual or others in the workplace. ${ }^{11}$

The statutory language of the ADA does not define direct threat. The EEOC regulation has been upheld by the Supreme Court as being valid and within the scope of the statute. Chevron U.S.A. Inc. v. Echazabal, 536 U.S. 73 (2002). The Title II regulation (which is part of the regulations issued in 2010) has not been subjected to judicial review.

Many in higher education have raised concerns about how the Title II regulation (not considering threat to "self") will be applied to actions towards students who are suicidal or who have other self-destructive behaviors such as severe depression or eating disorders.

One recent decision provides valuable guidance on dealing with students whose conduct raises issues of direct threat. In Stebbins v. University of Arkansas, 2012 WL 6737743 (W.D. Ark. 2013), the court addressed accommodation of a student with "intermittent explosive disorder" who had engaged in tactless behavior with a faculty member. The court discussed the student's repeated incidents of misconduct applying the "direct threat" analysis and determined that the student did not have to be readmitted because he was not otherwise qualified.

Schurb v. University of Texas Health Sciences Center, 2014 WL 5429307 (S.D. Tex. 2014). It did not violate Section 504 to remove a medical school student who had intentionally tried to harm himself by

1028 C.F.R. $\S 35.139($ b).

11 See $29 \S \S 1630.2(4) \& 1630.15(b)(2)$. 
drinking antifreeze. The student did not provide treating psychiatrist certification that he was not a danger to self or others.

A settlement in 2015 between the Department of Justice and Quinnipiac University involved a student who was dismissed because of mental health issues (ADA 2015a).

\section{Architectural Barriers}

Architectural barrier issues do not receive a great deal of judicial attention in higher education cases, but they are nevertheless important. Section 504, the ADA, and the Fair Housing Act have all treated new construction, existing construction, and renovations and alterations differently. This is a balancing of the burdens in varying contexts. The recent cases noted below, however, highlight the importance of remaining vigilant on these issues. In particular, the McNeese State decision reminds higher education institutions of the potentially high cost in time, resources, and reputation for failing to ensure access not only for stadiums and housing, but also for restrooms on campus. Issues of parking also arise under these discussions. In addition to architectural barriers, other access issues such as access for communication at sporting events may also fall under this topic of judicial attention. Policymakers should keep in mind that it is not only students, faculty, and staff who are affected by architectural barriers, but visitors of many types-such as clients and patients in clinics, alumni events, recruiting of new student events. Those on campus responsible for physical plant issues, should remain current on the evolution of the Universal Design movement, which facilitates access not only to individuals with disabilities, but for many others.

Adams v. Montgomery College, 2011 WL 261093 (D. Md. 2011). The court allowed a claim by a student regarding inadequate parking accommodations during a period of construction.

Cottrell v. Rowan University, 786 F. Supp. 2d 851 (D.N.J. 2011). Advocates for disability rights did not have a standing in a claim on behalf of an individual with a disability. The claim involved an advocacy group's attempt to monitor handicap parking violations. The court found that the ban from campus was not retaliation, because the ban was based on activity that was hostile, harassing, disruptive, and aggressive.

Covington v. McNeese State University, 118 So.2d 343 (S. Ct. La. 2013). The court reversed some of the attorney fee awards and held that the district court decisions on the amounts was not an abuse of discretion, but it did not overrule any of the substantive issues. For the facts in this case that lead to the decision, see Covington v. McNeese State University, 98 So.3d 414, 2011-1077 (La.App. 3 Cir.). The court ordered substantial award in attorneys' fees and costs in the case involving 15,000 architectural barriers; the court noted the university's "prolonged 'militant' behavior" over several years of litigation. The initial claim involved the lack of accessible restrooms in the student center.

Grutman v. Regents of University of California, 2011 WL 3358265 (N.D. Cal. 2011). The court declined to exercise supplemental jurisdiction over a claim involving a college student's case that each day her disability affected her ability to open her dorm door was a new violation of state law. The university contended a continuing violation that should cap damages.

Innes v. Board of Regents of University System of Maryland, 29 F. Supp. $3 d 56$ (D. Md. 2014). The court allowed the case to go forward in ADA/504 claims by spectators with hearing impairments that the university did not provide effective communication at athletic events and on sports websites.

Ross v. City University of New York, 211 F. Supp. 3d 518, 2016 WL 5678560 (E.D.N.Y. 2016). The court denied a motion to dismiss a former student's ADA/504 claim. The student with cerebral palsy alleged barriers to accessing campus. Standing issues were raised because she was an alum and not a current student which also included whether the close proximity to campus and issue of intent to return gave standing. 


\section{Accommodations}

Reasonable accommodations fall under two different major categories. These are auxiliary aids and services and modification of policies, practices and procedures. Both issues continue to receive judicial attention.

\subsection{Auxiliary Aids and Services}

Auxiliary aids and services can include interpreters, provision of materials in alternate formats, and note takers. Recent cases on this issue have addressed a wide range of fact-specific settings and highlight the importance of having a process in place for requesting such accommodations not only for students, faculty, and staff, but also for those attending public events and using services of professional education programs such as health clinics.

Argenyi v. Creighton University, 2011 WL 4431177 (D. Neb. 2011). A medical student with significant hearing loss requested communications access real time transcription, and interpreters as accommodation. The student could not show that certain accommodations would be necessary, although they were helpful. The court gave deference to faculty decisions. This case highlights the unclear standard about whether to be "reasonable" the accommodation must be "necessary".

Innes v. Board of Regents of University System of Maryland, 2015 WL 4716085 (D. Md. 2015). ADA/Rehab Act claims by college sports fans with hearing impairments were not moot. The provision of hand-held devices and installation of ribbon boards to caption the announced portion of events did not provide reasonable expectation that the university would not return to prior practices denying services.

Johnson v. Washington County Career Center, 2013 WL 6000925 (S.D. Ohio 2013). Reasonable issues remained regarding reasonable accommodations that should have been provided to a student with dyslexia; student requested reading device for tests; scanning course materials into device and word bank; student sometimes received graded assignments back later than other students.

Mapp v. Board of Trustees of Community College District 508, 53 Natl' Disability L. Rep. II 147 (N.D. Ill. 2016). The court found that triable issues existed in a case where a professor made a statement to a student with visual impairment on the second day of class indicating concerns that the student would not be able to complete the class. The professor's statements could be sufficient to demonstrate exclusion even if it was not intended to deny benefits or services.

Millay v. Maine Department of Labor, Bureau of Rehabilitation, 762 F.3d 152 (1st Cir. 2014). Addressing whether the blind commuter student in the culinary arts program should be provided with reimbursement for commuting expenses. The decision was made only on the procedural issue.

Saffold v. South Suburban College, 53 Nat'l Disability L. Rep. II 148 (N.D. Ill. 2016). In Title II and Section 504 claims by a student the court found that there were triable issues. The court held that direct evidence of discriminatory animus is not required. The student with a visual impairment had been approved for accommodations, including a note taker. The statements by the manager of the students services, that the note takers did not know how to work with visually impaired students, could be sufficient to show failure to accommodate.

Sellers v. University of Rio Grande, 838 F. Supp. 2d 677 (S.D. Ohio 2012). Although ordinarily tutors are not required, where services are provided to general population they must be provided to students with disabilities. The case involved disputed facts about whether a nursing student had been prevented from accessing these services.

Wolff v. Beauty Basics, Inc., 887 F. Supp. 2d 74 (D.D.C. 2012). The court allowed a claim to proceed for a deaf prospective student who was denied a sign language interpreter during the enrollment process. 


\subsection{Modification of Policies, Practices, and Procedures}

Auxiliary aids and services generally require direct financial resource commitments, and while some modifications of policies, practices, and procedures may not require a financial cost, they may raise issues of fundamental alteration. Others, such as additional testing time, may require planning for resources such as separate rooms and paying proctors and monitors, and these costs have become an increasing topic of attention for institutional planners. Some requests are unusual and require particularly creative approaches and attention to the interactive process.

Accommodations can also include

- $\quad$ additional time for exams

- other exam modifications (separate room; extra rest time)

- reduction, waiver, substitution, or adaptation of course work

- extensions on assignments

- extension of time for degree completion

- preference in registration

- permission to tape record classes

- modification of attendance requirements

- modification of policies, practices and procedures

Campbell v. Lamar Institute of Technology, 2016 WL 6915527 (5th Cir. 2016). The court affirmed the summary judgment for the college in a claim of intentional discrimination against a student with brain injury. Accommodations of extended time and note-taking assistance had been provided. The request for separate individually prepared exams was denied because of the burden to the faculty and unfair advantage.

Class v. Towson University, 51 Nat'l Disability L. Rep. II 103 (D. Md. 2013). A student who had previously suffered heat stroke and liver failure could be reasonably accommodated in the university football program. The requested accommodations of wearing additional padding to protect the students' abdomen and having temperature monitored were not unduly burdensome or a fundamental alteration.

Doe v. Samuel Merritt University, 921 F. Supp. $2 d 958$ (N.D. Cal. 2013). A student with anxiety disorders claimed the right for additional opportunities to take the medical licensing exam. The court allowed the case to go forward on issues of whether test-taking is a major life activity and whether a limit on taking exams was entitled to deference.

Guckenberger v. Boston University, 8 F. Supp. 2d 82 (D. Mass. 1998). The university had demonstrated that waiving foreign language would be a fundamental alteration of the program.

Guckenberger v. Boston University, 974 F. Supp. 106 (D. Mass. 1997). Course substitution for foreign language may be a reasonable accommodation; course substitution in math was not; $\$ 30,000$ in damages was awarded to the students.

Halpern v. Wake Forest University Health Sciences, 669 F.3d 454, 2012 WL 627788 (4th Cir. 2012) Medical student with ADHD and anxiety disorder did not request accommodations until several years after engaging in unprofessional acts, including abusive treatment of staff and multiple unexcused absences; proposed accommodation (allowing psychiatric treatment, participating in program for distressed physicians, and continuing on strict probation) was not reasonable.

Healy v. National Board of Osteopathic Medical Examiners, 2012 WL 1574783 (S.D. Ind. 2012). Case involved taking exams with accommodations for student with ADHD.

Herschman v. Muhlenberg College, 17 F. Supp. 3d 454 (E.D. Pa. 2014) The court allowed a case by a former college student with depression to proceed. Student claimed ADA violations and negligent infliction of emotional distress. There was an issue of whether the requested class substitution is a fundamental alteration. It was not appropriate to dismiss the case of the student seeking to substitute 
a class when facts had not been considered regarding fundamental alteration including the major and nature of courses involved.

Hoppe v. College of Notre Dame of Maryland, 835 F. Supp. 2d 26 (D. Md. 2011). Reasonable accommodations for comprehensive examinations for student with ADD had been provided. It was not required that she be given an additional opportunity to pass the exam.

Ladwig v. Board of Supervisors of Louisiana State University and Agricultural and Mechanical College, 2012 WL 292508 (M.D. La. 2012). A doctoral student with depression and anxiety did not make out Title I or Title II case. The student did not make out the case that she was qualified to perform essential functions of graduate assistantship. She did not adequately request accommodations for head injury excusing her from attendance and allowing additional time to turn in assignments. The university had provided accommodations by providing letters supporting absences and extra time.

McInerney v. Rensselar Polytechnic Institute, 2013 WL 4614263 (N.D.N.Y. 2013). Graduate student with permanent brain damage was allowed only one break during doctoral candidacy exam. This was not a denial of reasonable accommodation; the student could have, but did not ask for additional breaks.

Reichert v. Elizabethtown College, 2012 WL 1205158 (E.D. Pa. 2012). A student with ADHD had been given numerous modifications. The student requested and was granted medical withdrawal after disciplinary issues. Student could not make out a claim for "constructive discharge" from the academic program.

Shaikh v. Lincoln Memorial University, 50 Nat'1 Disability L. Rep. II 80 (E.D. Tenn. 2014). A student dismissed from an osteopathic medicine program was not otherwise qualified because of academic deficiencies. Accommodations had been provided (additional exam time, access to lecture notes, class video recordings). Requested accommodations of deceleration of the program was made after a dismissal recommendation and would be unreasonable because it would require changes to the clinical program, financial aid, and accreditation procedures.

T.W. v. Hanover County Public Schools, 900 F. Supp. 2d 659 (E.D. Va. 2012). The court found that there was no obligation on the college under IDEA to offer free tuition to a student with disability after graduation from high school. The state required free education only through high school graduation.

\subsection{Testing Accommodations_-"Best Ensures"}

One type of accommodation that has received substantial judicial attention is test accommodations for admissions tests and professional licensing exams that are often a conduit from a professional education program (such as law or medical field). Some of the recent decisions on this topic are listed below.

For regulatory guidance, see (ADA 2014).

Decisions listed below have all involved sensory impairments and examinations, which is what the regulations provide for.

Bonnette v. District of Columbia Court of Appeals, 43 Nat'l Disability L. Rep. II 173 (D.D.C. 2011). The court applied the "best ensures" standard from ADA regulations requiring bar examiner to allow use of certain technology.

Elder v. National Conference of Bar Examiners, 2011 WL 672662 (N.D. Cal. 2011). The court issued a preliminary injunction allowing the use of screen reader on the bar exam for applicant with a visual impairment.

Enyart v. National Conference of Bar Examiners, Inc., 630 F.3d 1153 (9th Cir. 2011). The court allowed a preliminary injunction for a bar exam applicant who was blind who had been denied a computer accommodation she had used throughout law school and on the California bar exam. The court applied the "best ensure" standard.

Jones v. National Conference of Bar Examiners, 43 Nat'l Disability L. Rep. II 224 (D. Vt. 2011). The court issued a preliminary injunction allowing a bar applicant with visual impairment to use screen access software on the Multistate Professional Responsibility Exam. 
Saavedra v. Board of Regents of University of Wisconsin System, 982 F. Supp. 3d 879 (E.D. Wis. 2014). Whether a resident physician with dyslexia, ADHD and LD should receive additional time on medical licensing exam. Court granted motion to dismiss.

\subsection{Service and Support Animals}

One of the issues receiving ongoing attention on campus is that of allowing animals on campus and at university events. While substantial regulatory guidance has been provided on that issue, new issues not completely answered by this guidance are being raised. These include how to address allergies and phobias of others in proximity to an assistance or emotional support animal. A forthcoming article by the author addresses many of these issues in a range of contexts. While there is less recent judicial attention to this issue in campus settings than in other contexts (housing, airlines, other public places and spaces), those who provide student services are resolving these issues and developing policies as these new questions arise. In particular, the application of the federal requirements in campus housing settings can be confusing because of the overlap between the ADA and the Fair Housing Act.

Department of Justice regulations for Title II and Title III only require inclusion of dogs (and miniature horses) but only allow a program to request minimal documentation-asking two questions:

- Is the dog a service animal required for a disability?

- What work or task has the dog been trained to perform?

The program cannot ask for official "documentation" or require the animal to wear a special coat. The animal must be under control.

In July 2015, the Department of Justice released an eight-page guide about service animals.

Full Document: United States Department of Justice, Frequently Asked Questions About Service Animals and the ADA, Civil Rights Division, 20 July 2015 (ADA 2015b).

Alejandro v. Palm Beach State College, 2011 WL 7400018 (S.D. Fla. 2011). The court granted a temporary injunction to a student seeking to bring a psychiatric service dog to campus and classes. The dog was trained to alert her to impending panic attack.

Rebecca J. Hussal, Canines on Campus: Companion Animals at Postsecondary Educational Institutions, 77 Mo. L. Rev. 417 (2012). See also “Campuses Debate Rising Demands for 'Comfort Animals'" (Hoffman 2015).

\section{Campus Housing-Implications re: Animals}

How is university housing to be treated? The 2010 Department of Justice regulations seem to indicate that campus housing as being subject to Titles II and III. 28 C.F.R. $\S 35.151$ (f) (Title II) and $\S 36.406$ (f) (Title III). It is not clear whether fraternity and sorority housing falls under the Private Club Exception, 42 U.S.C. § 12187, and the implications if Greek housing is subject to the ADA/FHA. The courts have not yet tested the validity of the DOJ regulations on this issue, nor have they clarified how the overlap of the FHA and the ADA on campus housing is to be applied regarding what animals are to be allowed and what documentation can be required.

The following case by the Department of Justice against Kent State University was denied dismissal by the federal court and focuses on applicability of FHA to campus housing, recognizing that some issues are not resolved (United States District Court 2015a).

United States v. University of Nebraska, 4:11CV 3209. 2013 WL 2146049 (D. Neb. 2013). The court decision determined that student housing at University of Nebraska is subject to the Fair Housing Act. This makes the university subject to HUD guidance related to support and service animals. A settlement was reached in 2015 setting up a policy for emotional support animals in university housing (United States Department of Justice 2016).

Velzen \& Fair Housing Center v. Grand Valley State, 902 F. Supp. 2d 1038, 2012 WL 4809930 (W.D. Mich. 2012). The court addressed the applicability of FHA and Section 504 to residential settings on campus. The case involved a student who had been prohibited from living with her guinea pig as a 
comfort animal to control stress. Although she had moved off campus, she was still enrolled and might still want to live on campus. The policy about animals had not changed so the case was not moot.

FHA case law in other contexts recognizes that animals that provide emotional support might be required as accommodations, but the programs might be allowed to require greater documentation.

\section{Technology Issues}

Obligations of institutions with respect to various technology issues are not clear. While the websites of these institutions are probably considered to be services that must be accessible, there are not yet standards that specify what the design of an accessible web page should be. Other issues important to plan for include technology issues arising in the context of course content-accessible materials, accessible power points, etc. The following are some of the recent developments relating to a range of technology issues.

The Communications and Video Accessibility Act (effective October 2013) requires that video content owners (not distributors) have the primary responsibility for captioning video information. 47 C.F.R 79.4(c)(1).

While there is some federal guidance on website accessibility, it is not certain under the current changes approach to administrative regulations and guidance, whether this is clear guidance (W3C 2008).

Several recent settlements and agency actions highlight the importance of universities taking a proactive approach to the use of technology on campus websites and in teaching materials.

OCR Resolution Letter and Agreement with South Carolina Technical College System (United States Department of Education 2013a; South Carolina Technical College System 2013).

Settlement between Department of Justice and Louisiana Tech University and University of Louisiana System (involving online learning program that excluded a blind student from the course) (United States Department of Justice 2013a; ADA 2013a) (prohibiting University from purchasing materials that are not accessible and providing guidance on faculty involvement in ensuring access.

See (University of Kansas 2015), student (demonstrating that students with disabilities are NOT taken into account generally in online learning programs).

Harvard and Yale were sued in February 2014 over their online course captioning. (Lewin 2015)

Settlement Agreement regarding Online Massive Online Course Accessibility at Massachusetts Institute of Technology and Harvard University—2 April 2015-addressing Title III case related to edX website and platforms that were not fully accessible to individuals with disabilities (United States Department of Justice 2015a, 2015b).

The Office of Civil Rights (OCR) has issued a resolution agreement with the University of Montana as a model for institutions to use to ensure their electronic and information technologies (EIT) are accessible and compliant with Section 508 of the Rehabilitation Act of 1973.

Dudley v. Miami University, DOJ complaint (alleging that the university violates Title II in the use of inaccessible websites and software for student usage because these technologies are incompatible with screen reader and other access technologies; materials were used as required parts of courses; failure to convert books in a timely manner); In the United States District Court for the Southern District of Ohio, Western Division-Cincinnati (United States District Court 2015b); In the United States District Court for the Southern District of Ohio, Western Division Case: 1:14-cv-00038-SAS Doc \#: 1 Filed: 01/10/14. (Ohio Disability Rights Law and Policy Center 2014) (original complaint)

Dear Colleague Letter 43 Nat'1 Disability L. Rep. II 75 (OCR 2011). The colleague letter advises universities that use of technology in classroom settings must either ensure full access to students with disabilities or provide an alternative that allows them to use the same benefits.

There have been a number of judicial decisions relating to a range of technology issues.

Argenyi v. Creighton University, 2011 WL 4431177 (D. Neb. 2011). A medical student with a significant hearing loss requested communications access through real time transcription and interpreters as accommodation. The student could not show that certain accommodations would be necessary, although they were helpful. The court gave deference to faculty decisions. 
Author's Guild v. HathiTrust, 902 F. Supp. 2d 445 (S.D.N.Y. 2012). This case addresses whether production of material in an alternate media is allowed by the fair use exception to the Copyright Act and protection under the Chafee Amendment; it affects taking published books and putting them on tape, on braille, large print, etc. On appeal, the court generally upheld the district court decision. Merely making information available to a broader audience is not transformative; providing material available to individuals with visual disabilities is fair use. (2d Cir. 2014) A settlement was entered on January 6, 2015. See generally, "Authors Guild v. HathiTrust Litigation Ends in Victory for Fair Use" (Cox 2015).

Innes v. Board of Regents of University of Maryland, 29 F. Supp. 2 d 566 (D. Md. 2014). This case addresses whether a university must provide certain transcription services on jumbo-trons and similar places at athletic events to ensure equal access to individuals who are deaf. The court allowed the case to go forward and recognized that compensatory damages could be required under Title II of the ADA and the Rehabilitation Act. The case also discussed how alternative technologies, such as hand-held devices at sports events, did not provide equal access.

National Association of the Deaf v. Netflix, Inc., 869 F. Supp. 2d 196, 2012 WL 2343666 (D. Mass. 2012). A subscription video company video streaming website is a place of public accommodation.

\section{Mental Health Issues}

Past incidents of shootings and violence on campus have raised questions about how to deal with students with mental health challenges and much attention has been devoted by a range of stakeholders on these issues. Those discussions are beyond the scope of this article. The issue does require attention to the following issues.

- Is the individual otherwise qualified?

- Are issues of direct threat and threat to self being raised?

- What are the FERPA implications and how is the duty to inform balanced with privacy rights?

- Are mental health services available on campus? It should be noted that most campuses are able only to provide very short term counseling services, and many students needs more.

\section{Returning Veterans}

Veterans with a range of health impairments including mental and physical impairments raise a unique issue in terms of documentation. For some requested accommodations-an emotional support animal for example-documentation of a mental health issue might be necessary. Unfortunately, obtaining such documentation quickly from military services can be a challenge. Institutions should anticipate this and decide whether to grant certain accommodations without the documentation at least for a limited time.

\section{Title IX for Students with Disabilities}

Although the obligations for accommodations in college sports were raised in 2013, little activity from the federal government followed this agency guidance. While it seems unlikely that separate and equivalent programs are required, it should be recognized that accommodations to athletes in mainstream programs should be considered.

Department of Education Office for Civil Rights has taken interest in the issue of equal athletic opportunities for students in educational programs. This is primarily an issue for K-12, but could have implications for higher education. A Dear Colleague Letter notes, on 25 January 2013, what is already required - that programs should provide reasonable modifications to rules and other requirements, although they need not make fundamental alterations to programs. The letter gives some examples and encourages separate programs in some instances (United States Department of Education 2013b, 2018). 


\section{Food Sensitivities and Allergies}

This issue has not received substantial recent judicial attention, but is an important planning issue. It is not clear whether all individuals with food sensitivities are disabled within the ADA definition. There are also issues of undue burden for some requested accommodations. The potential for requested accommodations on this issue should be addressed proactively.

There is little judicial guidance on this, and a Department of Justice settlement is not "precedent" but may provide insight into possible best practices for how universities might consider approaching this issue. The case involved a mandatory meal plan which did not address concerns for individuals with Celiac Disease. See Lesley University settlement (ADA 2013b) and question and answer guidance (United States Department of Justice 2013b). Some of the practices included answering questions about menu ingredients and changing ingredients upon request. While the settlement does note that only reasonable steps are required that do not fundamentally alter the program, it is not clear how these steps might be required for voluntary food plans; the case highlights the increasing interest in issues of food. This could apply to increasing concerns about peanut and gluten allergies.

Phillips v. PF Chang China Bistro, 2015 WL 4694049 (N.D. Cal. 2015). The court rejected that different charges for gluten-free alternatives were discriminatory. PF Chang was sued over higher costs for gluten-free items (Yahoo Health 2015).

Webb-Eaton v. Wayne County Community College District, 2013 WL 3835208 (E.D. Mich. 2013). Food allergies are not generally disabilities. The court recognized that the Department of Justice takes an alternative view.

\section{Eating Disorders-Relates to "Threat to Self" Issue}

Students (and others) with eating disorders raise questions about an institution's obligation to respond or to address proactively. There is not clear guidance from either the Department of Education or the courts on this issue.

\section{Faculty, Staff and Student Employment Issues}

While employment issues in higher education are necessarily different than employment in any other setting, faculty employment in particular can raise unique questions. It may be difficult to determine what the essential functions of a particular faculty position are and to assess whether a reasonable accommodation (such as tolling the time for promotion or tenure) must be allowed. As more baby boomers reach traditional retirement age, but do not retire (because mandatory retirement is no longer permissible), it is likely that more litigation will address these issues. Below are some of the most recent cases relevant to this discussion.

Ball v. Los Rios Community College Dist., 34 Nat'l Disability L. Rep. II 158, 2007 WL 755348 (E.D. Cal. 2007), on reconsideration in part on other grounds, 2007 WL 1791689 (E.D. Cal. 2007). The dismissal of an adjunct professor was based on absenteeism, failure to assign textbook, false statements, misrepresentation, and hostility towards a medical condition of Hepatitis-C.

Badwal v. Board of Trustees of the University of the District of Columbia, 139 F. Supp. 3d 295 (D.D.C. 2015). The court allowed the case to proceed where a faculty member requested delay to return because of an arm injury that denial of request to delay to return. The court allowed the FMLA to go forward on some issues. The case involved complex facts regarding notice and process for requesting leave.

Becker v. Gallaudet University, 66 F. Supp. 2d 1 (D.D.C. 1999). A faculty member who was deaf did not request accommodations in advance.

Boss v. Kettering University, 28 Nat'l Disability L. Rep. II 244, 2004 WL 1752961 (Mich. Ct. App. 2004). The court found that the following were not adverse employment actions: Preventing teacher with hypertension, depression, and mental impairments from teaching favorite class, requiring him to teach specific summer classes, changing location and size of classes, and use of surveillance to document timeliness. 
Carter v. Chicago State University, 50 Nat'l Disability L. Rep. II 103 (7th Cir. 2015). The denial of acting chair position was not an FMLA retaliation. There was an insufficient claim of temporal proximity of action and the failure to demonstrate evidence that the selected candidate was less qualified. (updating) Carter v. Chicago State University; 2013 WL 3975009 (N.D. Ill. 2013). There were issues of retaliation raised in not promoting a faculty member to chair position because of exercise of FMLA rights.

Lower court-Carter v. Chicago State University, 2011 WL 3796886 (N.D. Ill. 2011). An accounting professor with sleep apnea which was found not to be a disability under the 1990 ADA. Reasonable accommodations of scheduling had been provided in any case. It is possible that under ADAAA of 2008 , the sleep apnea would be a disability, but that the faculty member would still not be found to be otherwise qualified.

Caruth v. Texas A\&M University-Commerce, 2013 WL 991336 (N.D. Tex. 2013). The court granted summary judgment to the university in a denial of tenure case based on publication guidelines.

Craig v. Columbia College Chicago, 2012 WL 540095 (N.D. Ill. 2012). A college instructor with a hearing impairment was not denied a tenure track position based on his disability. The nonrenewal was based on offensive blog entries and email correspondence to a supervisor.

Coursey v. University of Maryland Eastern Shore, 2013 WL 1833019 (D. Md. 2013). A professor was required to undergo fitness for duty after aberrant behavior was not regarded as having a disability and issues of student safety were job-related.

Curtis v. University of Houston, 940 F. Supp. 1070 (S.D. Tex. 1996), aff'd, 127 F.3d 35 (5th Cir. 1997) A professor's denial of promotion was not based on alcoholism and a finding that a history of nonperformance related to drinking problems could be considered in the decision.

Dansby-Giles v. Jackson State University, 2010 WL 780531, 46 Nat'1 Disability L. Rep. II 65 (S.D. Miss. 2012). The court allowed the case regarding a professor claiming denial of a coordinator position and issues of an interactive process in accommodation process to go forward.

Davis v. Thomas Jefferson University, 26 F. Supp. 3d 1035, 1 Nat'1 Disability L. Rep. II 108 (E.D. Pa. 2015). The university employer is not required to compromise the collective bargaining agreement with terms about maximum medical leave by providing accommodations to an employee who had been injured and could not return to work that extended the leave.

Dugger v. Stephen F. Austin St. University, 54 Nat'l Disability L. Rep. II 149 (E.D. Tex. 2017). In a case brought by a state university policy officer with back injury seeking work accommodations (light duty), the court found that there were triable issues about whether the condition was a disability. The court found that there is no 11th Amendment immunity.

Ellis v. San Francisco State Univ., 53 Nat'l Disability L. Rep. II 127 (N.D. Cal. 2016). The court found that there were triable issues about fitness for duty resulting from evaluation for a faculty member whose behavior raised concerns. The issues included whether there was a failure to provide timely feedback and issues of outbursts and volatile interactions. There was an issue about what the director of HR knew at the time the evaluation was requested and its relationship to business necessity. There was a dispute about whether evaluation was related to fitness for the job.

Fuoco v. Lehigh University, 981 F. Supp. 2d 352 (E.D. Pa. 2013). A coordinator with ADD and depression who claimed discrimination did not establish that he had a disability or that the employer had notice of a disability. She had not made known any request for accommodations and legitimate reasons for termination were several errors in performance.

Gardiner v. Nova Southeastern University, Inc., 2006 WL 3804704 (S.D. Fla. 2006). The court denied summary judgment in a case where it was decided that determination of whether participation on a dissertation committee was essential depended on the factors of job description, time spent on task, experience of those who perform the job, and whether the position exists to perform the function.

Gardner v. Western Kentucky University, 2015 WL 5299451, 51 Nat' 1 Disability L. Rep. II 162 (W.D. Ky. 2015). The court granted summary judgment for the university. The professor did not show sufficient evidence of failure to accommodate and retaliation claims. The faculty member with 
autoimmune disorder requested to attend large department meetings remotely using interactive technology. A speakerphone had been provided. The court held that the employee had the burden of proposing reasonable accommodations.

Gascard v. Franklin Pierce University, 2015 WL 1097485, 50 Nat'1 Disability L. Rep. II 140 (D.N.H. 2015). Court denied the motion to dismiss an ADA claim by an art history professor. The issue was reasonable accommodation for situational stress in the claim of bullying and differential treatment claimed for other faculty members who were allowed to leave meetings.

Giraldo v. Miami-Dade College, 54 Nat'l Disability L. Rep. II 161 (S.D. Fla. 2017). The court granted a summary judgment to the college in a claim by a wheelchair user who applied for a tutorial position. The student was rejected because the student's English was not very clear, and the job required excellent oral skills and the ability to clearly articulate in the English language.

Hamilton v. Oklahoma City University, 911 F. Supp. 2d 1199 (W.D. Okla. 2012) judgment aff'd, (10th Cir. 2014). The court upheld the grant of judgment against a professor with vertigo who claimed discrimination in selection for a position. Two members of the selection committee were not aware of the condition.

Holmes v. Texas AEM University, 138 F.3d 168 (5th Cir. 1998). The opinion was withdrawn and superseded, 145 F.3d 681 (5th Cir. 1998). The court held that the statute of limitations began on the date of the initial written notice of termination in a claim of a tenured professor who experienced a stroke that dismissal violated ADA.

Hoppe v. Lewis University, 2012 WL 37647171 (7th Cir. 2012). A faculty member with clinically-diagnosed adjustment disorder had been provided interactive process to provide office locations and there were no ADA violation.

Horton v. Board of Trustees of Community College Dist. No. 508, 107 F.3d 873 (7th Cr. 1997). A community college professor who was terminated because of excessive absences was not otherwise qualified.

Housel v. Rochester Institute of Technology, 6 F. Supp. 3d 294 (W.D. N.Y. 2014). A lecturer was terminated based on poor performance and insubordination. The reasons were not a pretext for action when the claim was his FMLA request resulted in termination.

Hwang v. Kansas State University, 753 F.3d 1159 (10th Cir. 2014). The court held that it was not inherently discriminatory to deny extended sick leave to a professor who could not work.

Kortyna v. Lafayette College, 47 F. Supp. 3d 225 (E.D. Pa. 2014). A college professor requested as an accommodation that his personal attorney be present during disciplinary proceedings related to sexual harassment complaints. The claimed disability was adjustment disorder (debilitating anxiety and depression). The court found no violation of Title I or Section 504 in denying the request. Other accommodations at the hearing had been provided using good faith interactive process. There is no entitlement to requested or preferred accommodation, only reasonable accommodation.

Lamvermeyer v. Denison University, 114 F.3d 1187 (6th Cir. 1997). It was not an ADA violation to fire a professor who submitted fraudulent vouchers while under the influence of medication for anxiety.

Lupyan v. Corinthian Colleges Inc., 761 F.3d 314 (3d Cir. 2014). The case involved a procedural issue regarding receipt of notice of FMLA rights for an instructor with depression.

Maddox v. University of Tennessee, 62 F.3d 843 (6th Cir. 1995) (abrogated by, Lewis v. Humboldt Acquisition Corp., Inc., 681 F.3d 312, 26 A.D. Cas. (BNA) 389 (6th Cir. 2012). The Maddox decision involved adverse employment action against a coach who claimed his actions were caused by his alcoholism. The court found that the actions were based on conduct, not status.

Marshall v. Keene State College, 147 N.H. 215, 785 A.2d 418 (2001). A professor with depression did not show that the institution's mental health benefits plan, with a lifetime cap on benefits, violated the ADA.

Moore v. University of Kansas, 124 F. Supp. 3d 1159 (D. Kan. 2015). The court addressed the issue of immunity in a case by a faculty researcher claiming hostile work environment and whistleblower retaliation. The individual had been terminated for disruptive and unprofessional behavior. 
Motzkin v. Trustees of Boston University, 938 F. Supp. 983 (D. Mass. 1996). The court held that psychological problems did not excuse performance problems that resulted in termination.

Newberry v. East Texas State University, 161 F.3d 276 (5th Cir. 1998). A photography professor was dismissed because of work performance and lack of collegiality, not because he was perceived as disabled because of his obsessive-compulsive disorder.

Owens-Hart v. Howard University, 220 F. Supp. 3d 81 (D.D.C. 2016). A ceramics professor with asthma sought accommodations of cleaning and ventilating the ceramics studio. The decision involved a statute of limitations issue regarding the requests for accommodations.

Paststrump v. Southern Utah University, 50 Nat'1 Disability L. Rep. II 109 (D. Utah 2015). A professor with lupus, fibromyalgia, and chronic anemia was suspended based on performance deficiencies (failure to turn in document on time). The court found that accommodations to the teaching schedule had been provided.

Redlich v. Albany Law School of Union University, 899 F. Supp. 100 (N.D. N.Y. 1995). A law school professor who suffered stroke and lost use of left hand was not impaired within the Rehabilitation Act definition. This case was decided before the 2008 amendments to the definition and might be decided differently today.

Silk v. Board of Trustees, Moraine Valley Community College, Dist. No. 524, 795 F.3d 698 (7th Cir. 2015). An adjunct professor with a heart condition requiring triple bypass surgery was terminated because of his work, including problems with syllabi, using wrong textbook, poor attendance in courses and a non-participatory classroom environment with students playing video games and talking on the phone.

Tse v. New York University, 2013 WL 5288848 (S.D. N.Y. 2013). The court denied the university's motion for summary judgment, finding that there were triable issues on the issue of reasonable accommodation. The professor had lost status as a program director. The court held that the employer was not required to provide preferred accommodation to faculty member with severe arthritis and lupus, but questions remained about whether the university engaged sufficiently in the interactive process.

Vosatka v. Columbia University, 2005 WL 2044857 (S.D. N.Y. 2005). The court found that a request to undergo a psychological exam was not sufficient to indicate that the employer regarded a faculty member as disabled. The request followed erratic and inappropriate behavior.

Wallace v. Heartland Community College, 48 F. Supp. 3d 1151 (C.D. Ill. 2014). The court granted summary judgment to the college in a claim by a tenured biology professor with fibromyalgia and osteoarthritis that she had been constructively discharged and harassed by failure to provide requested accommodations.

Weigert v. Georgetown University, 120 F. Supp. $2 d 1$ (D.D.C. 2000). A university research assistant with neurological disorders and claustrophobia was not disabled under ADA (decided pre 2008 amendments). The dismissal was based on rude and abrasive interactions with other employees.

\section{Articles on Faculty/Staff Issues}

Sarah Brown, How 4 Professors Built Careers Despite Mental-Health Struggles, Chronicle of Higher Education, pp. B8-B10 (23 September 2016).

Lisa Cook, http:/ / www.academicimpressions.com/news/managing-aging-higher-ed-workfo rce-how-address-mental-health-issues-and-create-retirement Managing An Aging Higher Education Workforce: How to Address Mental Health Issues and Create Retirement Possibilities, 7 December 2015.

Barbara A. Lee and Judith A. Malone, As the Professoriate Ages, Will Colleges Face More Legal Landmines? The Chronicle of Higher Education B6-B8 (30 November 2007).

Suzanne Abram, The Americans with Disabilities Act in Higher Education: The Plight of Disabled Faculty, 32 Journal of Law \& Education 1 (2003) (detailed discussion of cases involving faculty members who won their cases). 
Lawrence C. DiNardo, John A. Sherrill, \& Anna R. Palmer, Specialized ADR to Settle Faculty Employment Disputes, 28 Journal of College \& University Law 129 (2001).

Barbara A. Lee and Peter H. Ruger, Accommodating Faculty and Staff with Psychiatric Disabilities, NACUA Publication Series (1997).

\section{Other Issues}

Alumni Cruises LLC v. Carnival Corp., 2013 WL 6511737 (S.D. Fla. 2013). The court allowed issues to be tried on whether the cruise line had made reasonable modifications; organization was allowed to have standing to bring these claims. This case raises the question about university "sponsored" and "facilitated" programs and their obligations for such programs.

\section{Shrinking Resources-Undue Burden as a Defense?}

As university budgets become increasingly challenged, it is probable that more litigation will raise the defense of undue financial burden.

\section{Legislative and Administrative Changes Since 2017-New Presidential Administration and New Congress}

The burden on higher education of regulations is raised by Scott Carlson, Tangled in Red Tape: Multiplying Regulations Bring Colleges New Costs and Headaches. For What? Chronicle of Higher Education, (21 November 2014) Page A18.

The Trump administration policy of reducing regulation and enforcement is likely to affect higher education. At this time, it is premature to assess to what degree, but the following are aspects of federal policy that should be monitored.

- Legislation-Will the ADA, Section 504, or the FHA be amended, repealed?

- Appropriations-How will federal budgets directly and indirectly affect financial resources available for accommodations?

- Regulations-Several sets of regulations are being re-evaluated and guidance documents are being withdrawn.

- Enforcement-How much priority will be given to staffing and focusing on accessibility issues on campus within in the Department of Justice and the Department of Education.

- Research and grant funding-The development of sound policies depends on high quality research. How is that being prioritized within relevant agencies?

\section{Proactive Approach to ADA Implementation}

Having effective policies, practices, and procedures (and personnel) for addressing proactively, reactively, and interactively the implementation of disability law on campus may benefit from ensuring personnel who are in a position to facilitate such policies. A thoughtful approach to this may be of value before federal agencies (Office for Civil Rights) contact a campus about a complaint. The value is not only to avoid liability, but also to gain positive public relations and to avoid unnecessary negative media attention.

Issues that should be considered in this regard include the following:

Personnel—to whom should disability questions be referred?

Policies and Procedures-is something already in place that addresses the issue? What areas should be prioritized for preparing such policies and procedures.

Preparation - training - to avoid the conflict or issue attention in the first place.

One recommendation is that universities create (or adapt) a position for an "ADA Coordinator". While most higher education institutions have a student services coordinator for disability issues and a "504" / HR person to address faculty and staff issues, many (most?) do not have a single person responsible for coordinating and addressing all of the ADA/504 issues that might arise on campus. 
Models exist for this on many campuses. Some of them are part of a joint position as ADA/Title IX coordinator. Others are responsible only for ADA/504 issues. There are many benefits of having such a coordinator.

The following provides issues to be addressed in creating or changing such a position.

To whom does a person report to?

- Provost

- President

- Human resources

- Other

Lines of coordination to key administrators

- Athletics directors

- Housing

- Student services

- Parking

- Physical plant

- Technology

What is the authority? It is essential that this be coordinated with university counsel.

- Dispute resolution

- Ombudsperson

- Coordinator

- Policy development

What are the areas of possible oversight?

- Students

- Faculty

- Staff

- Physical plant (including parking and sidewalks)

- Food services

- Health services (including mental health services)

- Housing

- Access areas (libraries, sports and performance arenas, student centers)

- Alumni events

- Transportation systems on campus

- Programs abroad

- Athletics

- Health care programs

- Technology

- Fraternities and sororities (special issues of "private clubs" require attention)

The following are some additional areas for consideration that do not necessarily fall into various topic areas.

- Facilities

- Websites

- Events (on and off campus) 
- Faculty awareness

- Does checking every box guarantee "compliance"

- Consider doing regular "self-evaluation" updates

What skills and characteristics are key for an ADA Coordinator?

- Knowledge of law

- Knowledge of disability issues

- Communications skills

- Ability to multitask

The concept of advisory committee for this position includes the following issues for consideration:

- Benefits of having such a committee

- Who should be on it

- Responsibilities

- Meetings

- Reports and records of meetings

What are some areas where proactive policy should be considered (whether through an ADA coordinator or other mechanism)?

- Animals on campus (including all settings_-housing, classrooms, employment settings, eating areas, etc.)

- Documentation for students receiving accommodations

- Dispute resolution—students; staff; faculty

- Technology (particularly website issues)

- Housing

- Faculty evaluation and appointment

- Mental health issues

Issues of training are challenging because of the various individuals who might benefit from training, limited time, changing personnel, and other factors. The following should be considered in developing the range of training programs valuable to a proactive approach.

- $\quad$ Student services

- Faculty (deans, associate deans, department chairs)

- Heads of key areas-housing, libraries, athletics, etc.

- How often (recognizing limited time and change of personnel)

- In what format? On line? In person? Content?

- Distribution of policies to key personnel—by whom, avoiding information overload

The following is an example of implementing a proactive approach for faculty.

- Letter of appointment-essential functions

- Annual and other review processes

- HR policies on accommodation requests should be made known

- Ensuring compliance with privacy and confidentiality of information-challenge in committee review process

- Interactive process in considering reasonable accommodations

- Internal disciplinary and dismissal procedures 
- Ensuring consistency for all similarly situated faculty in providing accommodations for situations other than disabilities

- Notice and due process

- Providing retirement and other human resources counseling and planning

In implementing policies, practices, and procedures for ALL areas, the following are guiding principles:

- Be interactive

- Be proactive

- Be consistent

- Provide individualized approach

- Ensure access to procedures (websites, etc.)

- Avoid "over-accommodation" (to ensure that policies can be implemented fairly and consistently)

Basic principles for this discussion include the following:

- Taking a holistic approach—avoiding silos

- Having good communication with all stakeholders

\section{Bio Summary—Laura Rothstein}

Professor of Law and Distinguished University Scholar

University of Louisville, Louis D. Brandeis School of Law

B.A., University of Kansas; J.D., Georgetown University Law Center

Laura Rothstein has been involved in disability discrimination issues since 1979, when she represented clients with disabilities while a faculty member at the University of Pittsburgh School of Law in its Developments Disabilities Law Project clinical program. Since 1980, she has written three books (all in numerous editions) and dozens of book chapters, articles, and other works on disability discrimination, covering a broad range of issues, with an emphasis on disability discrimination in higher education and special education.

She has applied her knowledge through service in several national organizations-National Association of College and University Attorneys, ABA Section of Legal Education and Admission to the Bar, Law School Admission Council, Association of American Law Schools, Association of Higher Education and Disabilities, and others and in administrative positions-Associate Dean for Student Services (University of Houston Law Center from 1986 to 1993), Associate Dean for Graduate Studies (University of Houston Law Center 1999 to 2000), and Dean (University of Louisville Brandeis School of Law 2000 to 2005). From 1980 to 1986, she served as the Faculty Editor of the Journal of College and University Law (co-published at that time by the National Association of College \& University Attorneys and West Virginia University College of Law). She currently is a member of the JCUL Editorial Advisory Board.

She is frequently consulted by advocates, government agencies, university administrators, and university counsels about these issues, and her perspective is one of an "advocate through education." Her goal is to influence policy and practice by increasing awareness and understanding of legal requirements, and how they can be implemented before disputes arise.

She received the William A. Kaplin Award for Excellence in Higher Education Law and Policy Scholarship from the Center for Excellence in Higher Education Law and Policy 2011, and an award for Outstanding Research and Creative Activity from the University of Louisville in 2012 and Brandeis School of Law Outstanding Teacher in 2015. In 2017, she received an award from the ABA Section of Property for an article she coauthored with Mark Rothstein on the use of genetic information in housing, as "Best Cutting Edge Article." 


\section{Reference of Scholarship by Laura Rothstein}

(Rothstein 1991) Rothstein, Laura. 1991. Students, Staff and Faculty with Disabilities: Current Issues for Colleges and Universities, 17 J.C. \& U.L. 471.

(Rothstein 1992) Rothstein, Laura. 1992. Disabilities and the Law. Chapter 3 (Higher Education) and Chapter 10 (Health Care) (Thomson Reuters 4th edition which is published in cumulative editions twice a year (with Julia Irzyk).

(Rothstein 1993) Rothstein, Laura. 1993. The End of Forced Retirement: A Dream or a Nightmare for Legal Education? ABA Syllabus (January 1993).

(Rothstein 1994) Rothstein, Laura. 1994. College Students with Disabilities: Litigation Trends. 13 REV. OF LITIGATION (University of Texas) 425.

(Rothstein 1997) Rothstein, Laura. 1997. Health Care Professionals with Mental and Physical Impairments: Developments in Disability Discrimination Law, 41 ST. LOUIS U. L. REV. 973.

(Rothstein 1997) Rothstein, Laura. 1997. Higher Education and Disabilities: Trends and Developments. 27 STETSON L. REV. 1 (Fall 1997)

(Rothstein 1997) Rothstein, Laura. 1997. Higher Education and Disabilities: An Overview of 1995 Cases. 23 J.C. \& U. L. 475.

(Rothstein 1997) Rothstein, Laura. 1997. The Employer's Duty to Accommodate Performance and Conduct Deficiencies of Individuals with Mental Impairments under Disability Discrimination Law," 47 Syracuse Law Review. SSRN Reference. Available online: http:/ / ssrn.com/author=37905.

(Rothstein 2000) Rothstein, Laura. 2000. Don't Roll in My Parade: Sports and Entertainment Cases and the ADA, 19 U. TEX. REV. OF LITIGATION 400.

(Rothstein 2000) Rothstein, Laura. 2000. Higher Education and the Future of Disability Policy, 52 U. ALABAMA L. REV. 241-270.

(Rothstein 2000) Rothstein, Laura. 2000. Reflections on Disability Discrimination Policy: 25 Years, 22 U. ARK. L. REV. 147-160.

(Rothstein 2004) Rothstein, Laura. 2004. Disability Law and Higher Education: A Roadmap for Where We Have Been and Where We May Be Heading, 63 MD. L. REV. 101.

(Rothstein 2007) Rothstein, Laura. 2007. Millennials and Disability Law: Revisiting Southeastern Community College v. Davis: Emerging Issues for Students with Disabilities, 34 J.C. \& U.L. 167.

(Rothstein 2007) Rothstein, Laura. 2007. Southeastern Community College v. Davis; Chapter in Education Stories. Edited by Michael Olivas and Ronna Schneider. Foundation Press.

(Rothstein 2008) Rothstein, Laura. 2008. Law Students and Lawyers with Mental Health and Substance Abuse Problems: Protecting the Public and the Individual," 69 U. PITT. L. REV. 531.

(Rothstein 2008) Rothstein, Laura. 2008. Strategic Advocacy in Fulfilling the Goals of Disability Policy: Is the Only Question How Full the Glass Is? 13 TEX. J. CIV. LIBERTIES \& CIV. RIGHTS 403.

(Rothstein 2009) Rothstein, Laura. 2009. Disability Law Issues for High Risk Students: Addressing Violence and Disruption, 35 J.C. \& U.L. 101.

(Rothstein 2010) Rothstein, Laura. 2010. Higher Education and Disability Discrimination: A Fifty Year Retrospective, 36 J.C. \& U.L. 843. Available online: http:/ / papers.ssrn.com/sol3/papers.cfm?abst ract_id=1653466.

(Rothstein 2011) Rothstein, Laura. 2011. Disability Rights, Encyclopedia of Diversity in Education. Thousand Oaks: Sage Publications.

(Rothstein 2011) Rothstein, Laura. 2011. Telescopes, Microscopes, and Crystal Balls: Disability Discrimination Law and Policy in Higher Education: How Those in Higher Education Can and Should Influence Policy. Paper presented at the National Conference on Law and Higher Education, the Center, Stetson University College of Law upon receiving the William A. Kaplin Award for Excellence in Higher Education Law and Policy Scholarship, 7 February 2011.

(Rothstein 2012) Rothstein, Laura. 2012. Litigation over Dismissal of Faculty with Disabilities, Appendix C of AAUP Report on Accommodating Faculty Members Who Have Disabilities. 
(Rothstein 2014) Rothstein, Laura. 2014. Disability Discrimination Statutes or Tort Law: Which Provides the Best Means to Ensure an Accessible Environment, 75 Ohio St. L. 1263.

(Rothstein 2014) Rothstein, Laura. 2014. Forty Years of Disability Policy in Legal Education and the Legal Profession: What Has Changed, and What Are the New Issues. American University Journal of Gender, Social Justice, and the Law 22: pp. 519-650.

(Rothstein 2014) Rothstein, Laura. 2014. IHELG Monograph, 14-04, 2014. Available online: http:/ / www.law.uh.edu/ihelg/monograph/14-04.pdf.

(Rothstein 2014) Rothstein, Laura. Forty Years of Disability Policy in Legal Education and the Legal Profession: What Has Changed and What Are the New Issues? Available online: http: / / papers.ssrn.com/sol3 / papers.cfm?abstract_id=2441240.

(Rothstein 2015) Rothstein, Laura. 2015. Impaired Physicians and the ADA, Viewpoint, 9 June 2015. JAMA 313: pp. 2219-20. Available online: http://jama.jamanetwork.com/article.a spx?articleid $=2319174$.

(Rothstein 2015) Rothstein, Laura. 2015. The Americans with Disabilities Act and Higher Education 25 Years Later: An Update on the History and Current Disability Discrimination Issues for Higher Education. 41 J.C. \& U.L. 531. Available online: http:/ / papers.ssrn.com/sol3/papers.cfm?abst ract_id=2629306.

(Rothstein 2018) Rothstein, Laura. 2018. Puppies, Ponies, Pigs, and Parrots; Policies, Practices and Procedures in Pads: Pubs, Pads, Planes and Professions: Where We Live, Work, and Play, and How We Get There: Animals Accommodations in Public Places, Housing, Employment, and Transportation. Lewis \& Clark Animal Law Review (in progress).

(Rothstein and Irzyk 2018) Rothstein, Laura, and Julia Irzyk. 2018. Disabilities and the Law, 4th ed. Eagan: Thomson Reuters.

Funding: This research received no external funding.

Conflicts of Interest: The author declares no conflict of interest

\section{References}

ADA. 2012. Revised ADA Regulations Implementing Title II and Title III. Available online: http:/ /www.ada.gov/ regs2010/ADAregs2010.htm (accessed on 27 June 2018).

ADA. 2013a. Settlement Agreement Between the United States of America, Louisiana Tech University, And the Board of Supervisors for the University of Louisiana System Under the Americans with Disabilities Act, DJ \#204-33-116. Available online: http:/ / www.ada.gov/louisiana-tech.htm (accessed on 27 June 2018).

ADA. 2013b. Settlement Agreement between the United States of America and Lesley University. DJ 202-36-231. Available online: http:/ / www.ada.gov/lesley_university_sa.htm (accessed on 27 June 2018).

ADA. 2014. Testing Accommodations. Available online: http://www.ada.gov/regs2014/testing_accommodation s.pdf (accessed on 27 June 2018).

ADA. 2015a. Settlement Agreement between the United States of America and Quinnipiac University under the Americans with Disabilities Act. Available online: http:/ /www.ada.gov/quinnipiac_sa.htm (accessed on 27 June 2018).

ADA. 2015b. Frequently Asked Questions about Service Animals and the ADA. Available online: https:/ /www. ada.gov/regs2010/service_animal_qa.pdf (accessed on 27 June 2018).

ADA. 2016. Amendment of Americans with Disabilities Act Title II and Title III Regulations to Implement ADA Amendments Act OF 2008 United States Department of Justice Civil Rights Division Disability Rights Section 1425 New York Avenue, N.W. Washington, D.C. 20005. Available online: https:/ /www.ada.gov/regs2016/f inal_ra_adaaa.html (accessed on 27 June 2018).

Cox, Krista. 2015. Authors Guild v. HathiTrust Litigation Ends in Victory for Fair Use. Available online: http:/ / www.arl.org/news/ community-updates/3501-authors-guild-v-hathitrust-litigation-ends -in-victory-for-fair-use\#.WzCFB3vYEx9 (accessed on 27 June 2018). 
Diament, Michelle. 2015. Graduation Rates Inch Up For Students with Disabilities. Disability Scoop. March 17. Available online: http://www.disabilityscoop.com/2015/03/17/graduation-rates-inch-up/20141/ (accessed on 27 June 2018).

Federal Register. 2015. Application for New Awards; National Center for Information and Technical Support for Postsecondary Students with Disabilities. Available online: https:/ / www.federalregister.gov / documents / 2015/06/19/2015-15191/application-for-new-awards-national-center-for-information-and-technical-sup port-for-postsecondary (accessed on 27 June 2018).

Hoffman, Jan. 2015. Campuses Debate Rising Demands for 'Comfort Animals'. Available online: http:/ / www.nytimes.com/2015/10/05/us/four-legged-roommates-help-with-the-stresses-of-ca mpus-life.html?emc=eta1\&_r=0 (accessed on 27 June 2018).

Lewin, Tamar. 2015. Harvard and M.I.T. Are Sued Over Lack of Closed Captions. Available online: http:/ / www.nytimes.com/2015/02/13/education/harvard-and-mit-sued-over-failing-to-caption-online - courses.html? \&hp\&action=click\&pgtype=Homepage\&module=second-column-region\&region=top-ne ws\&WT.nav=top-news\&_r=2 (accessed on 27 June 2018).

Ohio Disability Rights Law and Policy Center. 2014. In the United States District Court for the Southern District of Ohio, Western Division, Case: 1:14-cv-00038-SAS Doc \#: 1 Filed: 01/10/14. Available online: https:/ / nfb.org/images/nfb/documents/pdf/miami\%20teach.pdf (accessed on 27 June 2018).

The Office of Special Education and Rehabilitative Services (OSERS). 2017. A Transition Guide to Postsecondary Education and Employment for Students and Youth with Disabilities. Available online: https:/ www2.e d.gov/about/offices/list/osers/transition/products/postsecondary-transition-guide-2017.pdf (accessed on 27 June 2018).

Rothstein, Laura, and Julia Irzyk. 2018. Disabilities and the Law, 4th ed. Eagan: Thomson Reuters.

Samuels, Christina. 2015. Graduation Rates for Students with Disabilities on the Rise, Education Week, 23 March 2015. Available online: http://blogs.edweek.org/edweek/speced/2015/03/graduation_rate S_disabilities.html (accessed on 27 June 2018).

South Carolina Technical College System. 2013. Resolution Agreement, South Carolina Technical College System, OCR Compliance Review No. 11-11-6002. Available online: http:/ / www2.ed.gov/about/offices/list/ocr/ docs/investigations/11116002-b.pdf (accessed on 27 June 2018).

United States Department of Education. 2013a. OCR Resolution Letter and Agreement with South Carolina Technical College System. Available online: http:/ /www2.ed.gov/about/offices/list/ocr/docs/investigati ons/11116002-a.doc (accessed on 27 June 2018).

United States Department of Education. 2013b. Dear Colleague Letter. Available online: www.ed.gov/about/offic es/list/ ocr/letters / colleague-201301-504.pdf (accessed on 27 June 2018).

United States Department of Education. 2018. U.S. Departments of Justice and Education Receive 2018 Blue Pencil \& Gold Screen Award. Available online: http:/ /www.ed.gov/news/press-releases/us-department-educati on-clarifies-schools-obligation-provide-equal-opportunity-students-disabilities-participate-extracurricul ar-athletics (accessed on 27 June 2018).

United States Department of Justice. 2013a. Justice Department Settles with Louisiana Tech University Over Inaccessible Course Materials. Available online: http:/ /www.justice.gov/opa/pr/2013/July/13-crt-831.html (accessed on 27 June 2018).

United States Department of Justice. 2013b. Questions and Answers about the Lesley University Agreement and Potential Implications for Individuals with Food Allergies. Available online: www.ada.gov/q\&a_lesley_uni versity.htm (accessed on 27 June 2018).

United States Department of Justice. 2015a. Justice Department Reaches Settlement with edX Inc., Provider of Massive Open Online Courses, to Make Its Website, Online Platform and Mobile Applications Accessible under the Americans with Disabilities Act. Available online: http:/ /www.justice.gov/opa/pr/justice-department-re aches-settlement-edx-inc-provider-massive-open-online-courses-make-its (accessed on 27 June 2018).

United States Department of Justice. 2015b. Settlement Agreement between the United States of America and edX Inc. under the Americans with Disabilities Act. DJ No. 202-36-255. Available online: https:/ /www.justice.gov/si tes/default/files/opa/press-releases/attachments/2015/04/02/edx_settlement_agreement.pdf (accessed on 27 June 2018). 
United States Department of Justice. 2016. Justice Department and University of Nebraska at Kearney Settle Lawsuit over Rights of Students with Psychological Disabilities to Have Assistance Animals in Student Housing. Available online: https:/ / www.justice.gov/opa/pr/justice-department-and-university-nebrask a-kearney-settle-lawsuit-over-rights-students (accessed on 27 June 2018).

United States District Court. 2015a. Case: 5:14-cv-01992-JRA Doc \#: 46 Filed: 09/16/15 1 of 6. United States District Court, Northern District Of Ohio, Eastern Division. Available online: https://www.justice.gov/crt/ file/777336/download (accessed on 27 June 2018).

United States District Court. 2015b. In the United States District Court for the Southern District of Ohio, Western Division-Cincinnati. Available online: https://www.ada.gov/miami_university/motion_intervene.pdf (accessed on 27 June 2018).

University of Kansas. 2015. Researchers Conduct Extensive Examination of Online Learning for Students with Disabilities. Available online: http:/ / m.phys.org/news/2015-12-extensive-online-students-disabilities.h tml\#jCp (accessed on 27 June 2018).

W3C. 2008. Web Content Accessibility Guidelines (WCAG) 2.0. Available online: https:/ /www.w3.org/TR/WC AG20/ (accessed on 27 June 2018).

Yahoo Health. 2015. Why P.F. Chang's Is Being Sued over Its Gluten-Free Menu. Available online: https:/ /www.yahoo. com/health/why-p-f-changs-is-being-sued-over-its-109996603802.html?soc_src=mags\&soc_trk=ma (accessed on 27 June 2018).

(C) 2018 by the author. Licensee MDPI, Basel, Switzerland. This article is an open access article distributed under the terms and conditions of the Creative Commons Attribution (CC BY) license (http:/ / creativecommons.org/licenses/by/4.0/). 